\title{
International Journal of Educational Methodology
}

\author{
Volume 4, Issue 3, 133 - 139.
}

ISSN: 2469-9632

http://www.ijem.com/

\section{Achievement Motivation Analysis of Outstanding Students in Learning Writing at Primary Schools}

\author{
Ruksah Nur Kholisiyah * \\ Sebelas Maret University, INDONESIA
}

\author{
Rukayah \\ Sebelas Maret University, INDONESIA
}

\author{
Mintasih Indriayu \\ Sebelas Maret University, INDONESIA
}

Received: May 30, 2018 - Revised: June 22, 2018 - Accepted: July 12, 2018

\begin{abstract}
This study aims to describe achievement motivation on outstanding students in learning to write at the fifth grade primary schools students. The research method used is descriptive qualitative. Subjects in this study were 18 achieving students. The data were collected through questionnaire, interview and observation. Analytical techniques used are interactive analysis consisting of data collection, data reduction, data presentation and conclusion. The results of this study indicate that the achievement motivation on outstanding students in learning writing is good, this happens because of several factors that support outstanding students in learning writing have good achievement motivation. There are factors of individuals (intern) and environmental factors (external), an individual factor which consists of 1) the competence of students; 2) belief to succeed, while environmental factors consists of 1) the competitive situation; 2) support from parents, 3) schools, including how to teach teachers.
\end{abstract}

Keywords: Achievement motivation, outstanding students, learning writing, primary school.

To cite this article: Kholisiyah, R. N., Rukayah, \& Indriayu, M. (2018). Achievement motivation analysis of outstanding students in learning writing at primary schools. International Journal of Educational Methodology, 4(3), 133-139. https://doi.org/10.12973/ijem.4.3.133

\section{Introduction}

Based on the 2013 curriculum that began to be applied in Indonesia, it explains that the language is a defender of science, meaning that language is a means of conveying knowledge. All students will need language skills as a learning tool to master various other subjects. It can be said that the ability of students in the language greatly affect the success of students in learning, because the purpose of the subjects in primary school is to provide information to students, and the information in the form of language. In addition to the Curriculum 2013, Indonesian subjects are transformed into text-based learning. In this text-based learning, different types of texts are not only studied on the basis of their physical structure, but are also studied on the basis of their social context and emphasize students' understanding of different types of texts and require students to be proficient in writing.

Students find it more difficult to master writing competencies than other language competencies such as listening competence, speaking competence, and reading competence. This is confirmed by the opinion of Nurgiyantoro (2014: 422) which states that writing competence is more difficult to master, even by native speakers of the language though.

One of the writing learning materials that should be studied and mastered by primary school students is to write explanatory text. The explanatory text is a text describing the process of the occurrence or formation of a natural or social phenomenon (Isnatun\& Farida, 2013: 80). The explanatory text aims to explain the process of formation or activity related to the phenomena of natural, social, scientific, or cultural phenomena (Priyatni, 2014: 82).

Based on the results of writing an explanatory text that not all students get low results, there are some students who get the results of writing satisfactorily, they are students who excel in learning writing. Several factors that influence and support the results of the quality of writing students who excel in writing. In addition to knowledge and ability of students in writing, achievement motivation to write an internal factor to consider.

The word motivation is used to describe an impulse, need or desire to do something (Slavin 1991: 328). Meanwhile, according to Beck (1990: 21) said that motivation can not be directly observed to a person, but can be interpreted from his behavior. Meanwhile, according to Heckhausen (1967: 54) achievement motivation is the motive that encourages individuals to achieve success and aims to succeed in competition with certain standards of excellence. Motivation can

\footnotetext{
* Corresponding Author:

Ruksah Nur Kholisiyah, Department of Primary Education, Sebelas Maret University, Indonesia.

$\bowtie$ ruksah_n@yahoo.com
} 
explain the reasons why people decide to do something, where their decisions pursue their will, and how long they want to (Hassanzadeh \& Mahdinejad, 2015).

Based on the description, then interviewed the teacher of fifth grade in two public primary schools in Sragen regency. Researchers conducted interviews with the fifth grade teachers from each of these schools. From the interview activities obtained information that the overall competence of students in writing explanatory text is good enough. Students can find the main idea of the text content. Students can adjust the content of the summary with the text they are reading, but the students need to improve in using the right word choice, there are some students who have difficulty in using the word choice so using the word choice that is exactly the same as the original text. In addition, there are some students who mix with the local language. Students need to improve the proper use of spelling and grammar. In essence,

students have been able to write summaries of the explanatory texts even though the results are not very good and not bad.

Furthermore, observations on the implementation of learning to write a summary of the explanatory text in the fifth grade at two primary schools. The results of this observation indicate that the fifth grade teachers from both schools have done a good writing study. The teacher provides guidance to the students on how to summarize the good, but the students seem less interested in learning to write, the students show laziness and complain. Students in the classroom tend to be passive, some students say that they find it difficult to write long text or summarize a text and students that do not want to ask during the learning process takes place. Students are less motivated once to write, it is seen a lot of students who complain and refuse to write text.

To support these things, it is necessary to have an analysis of achievement motivation in students who excel in writing learning, so it can know what aspects are needed for teachers to increase students' motivation in learning writing.

\section{Literature Review}

Mc Clelland (1987) said that achievement motivation is a desire that exists within a person who encourages the person to try to achieve a standard or measure of excellence. Such motivation is associated with the purpose and the way to achieve it, planning, effort, and feelings of self-worth (Ghasemi, et al, 2011). Gagne and Barliner (1975: 77) add that achievement motivation is one's way of doing well for achievement. According to Uno (2013) achievement motivation effect on performance. Uno argues that achievement motivation can assist students in understanding and explaining the lesson. The following are important roles of achievement motivation are: (1) to know what drives a person in achieving goals, (2) to know the goals to be achieved, (3) to determine feedback, and (4) to determine perseverance in learning. The function of achievement motivation is to learn and develop, can direct and train in conducting learning activities, with attention to real effort and based on motivation, learning will be able to produce good achievement.

McClelland (1978: 77) suggests that there are six characteristics of individuals who have high achievement motivation, namely: first is a strong feeling to achieve the goal, which has the desire to complete the task with the best results; second, has the responsibility of being able to take responsibility for itself and determine its future, so that what is achieved is achieved; third, evaluative, ie using feedback to determine more effective actions for achievement; the fourth is to take the risk of "being" in the sense of its actions in accordance with the limits of its capabilities; Fifth is creative and innovative; and the latter the sixth is fond of the challenge. According to Back (1990: 304) mentions there are six dimensions of achievement motivation that is 1) status with experts; 2) persistence to obtain something or a particular purpose; 3) have the independence to achieve the achievement; 4) status with peers; 5) the existence of competition situation; 6) have attention to the advantages possessed.

Achievement motivation is very needed students in learning to write because students who have achievement motivation will have a high willingness to learn, diligent, and diligent in following the learning activities of writing, so that they become students who are proficient in learning to write. This is in accordance with research conducted by Lam and Law (2007) which states that motivation of students affect the writing performance, when students are more motivated, they in turn, have better performance in writing. Individuals who have achievement motivation usually prefer tasks that demand responsibility. This means success is achieved not because of the help of others or because of luck, but because of the hard work itself.

Based on the description, it can be seen the indicators of achievement motivation used to collect data in this study, the indicators used are based on the characteristics of achievement motivation according to Mc Clelland (1978), as follows: 1) strong feelings to achieve the goal; 2) responsible; 3) evaluative; 4) creative and innovative; 5) likes challenges.

\section{Methodology}

\section{Research Goal}

Research goal of the present study is to describe achievement motivation on outstanding students in learning to write at the fifth grade primary schools students. and to know factors that influence achievement motivation on outstanding students in learning to write in primary school. This information is very useful for references and considerations for 
other students to be motivated and motivated to excel in writing lessons and for teachers to know the importance of improving achievement motivation for writing students in learning to write explanatory text in primary school so that it can improve the result writing explanatory text.

\section{Sample and Data Collection}

The type of this research is descriptive research using qualitative approach. Descriptive research is aimed to describe a state or phenomenon as it is at the time of research conducted. Descriptive research describes a situation, but can also describe the state in the stages of development (Agung, 2014: 26).

The population of this research is all outstanding students of fifth grade in public primary school year 2017/2018, in Sragen regency. Sampling technique in this research is purposive sampling, that is chosen with consideration and certain purpose. In this case the researcher chose six public primary schools in Sragen regency to be used as sample in this research, primary school is Karanganom 1, Karanganyar 2, Pungsari 1, Sambiduwur 1, Gentanbanaran 1 and Bonagung 2, then writer choose 3 students from each sixth the elementary school that scores the highest in text writing tests. The selection of the students is based on the consideration of the fifth-grade teacher in each primary school. The number of samples in this study were 18 outstanding students in the fifth grade of the public primary school in Sragen regency. Data collection methods used in this study are questionnaires, interviews and observation. Given this research is qualitative research, the main instrument in this research is the researcher own (Moloeng, 2006; Sugiyono, 2011; Wahidmuri, 2008). Ogdan and Biklen (in Sugiyono 2011) stated that one of the qualitative research traits is done under natural conditions, (as opposed to experiments), directly to data, sources and researchers are key instruments. To obtain a wider and comprehensive data, the researcher uses a research instrument that is a questionnaire sheet, an interview sheet to obtain in-depth data of outstanding students and observation sheet.

To know the validity of questionnaire achievement motivation using construct validity and product moment statistic test. Test the validity of constructs using expert judgment performed by expert panel which includes researchers and two lecturers. Based on the calculation of validity test using Aiken formula formula, that is; $V=S /[n \times(c-1)] / S=\sum n i$ ( - lo). It can be concluded that all the questionnaire statements are valid in construction because the overall score of the calculated result is greater than 0.76 or greater than the $\mathrm{V}_{\text {Aiken }}$ index. After the validity test, a questionnaire was conducted to thirty students in the fifth grade of primary school. The test results are then analyzed by using SPSS to determine the validity of the questionnaire through product moment statistical test and reliability questionnaire with cronbachs alpha. The items of valid statement have $r$-count $>r$-table, that is $r$-table 0,361 (at $n=30$ with significance level 0,05$)$. All valid statements are 10 items, this is the instrument for data retrieval. Instrument reliability test results produce $r$-count $=0.916>$ r-table 0.361 . It can be concluded that the instrument of questionnaire statement is declared reliable.

\section{Analyzing Data}

The data analysis technique used is descriptive using Miles and Huberman model. The aactivities in the analysis include data reduction, data presentation (data display), conclusion drawing / verification (Miles \&Huberman, 1994:10). The calculation of the final value of the questionnaire data is analyzed by using the formula of Ridwan and Sunarto ( 2007:23) is the final value equal to the score obtained devided by maximum score multiplied by $100 \%$.

\section{Results}

The results of the observations in the writing lessons in primary schools show that: first, the process of writing learning is good, but teachers have not used various teaching methods and have not utilized the existing facilities, so less effective learning. Teachers do not discriminate students based on their achievement. The teacher presents the material clearly and systematically. Secondly, in the learning process of writing, achieving students are more enthusiastic and they complete the task with the ability they have. They can give many answers to the questions given by the teacher. Third, in learning writing, achieving students try to do the task and not complain much like the others and submit the task of writing on time.

\section{Describe of questionnaire achievement motivation}

Based on indicators of achievement motivation, each indicator consists of two statements, so the total statement that the student must answer is ten statements, there are positive statements and negative statements. The answers from each statement using five alternative answers strongly agree, agree, doubt, disagree, strongly disagree. The most positive answers are given score 5, so on 4, 3, 2 and most negative score 1 . The following elaboration of the results of achievement motivation analysis on outstanding students in learning to write. 


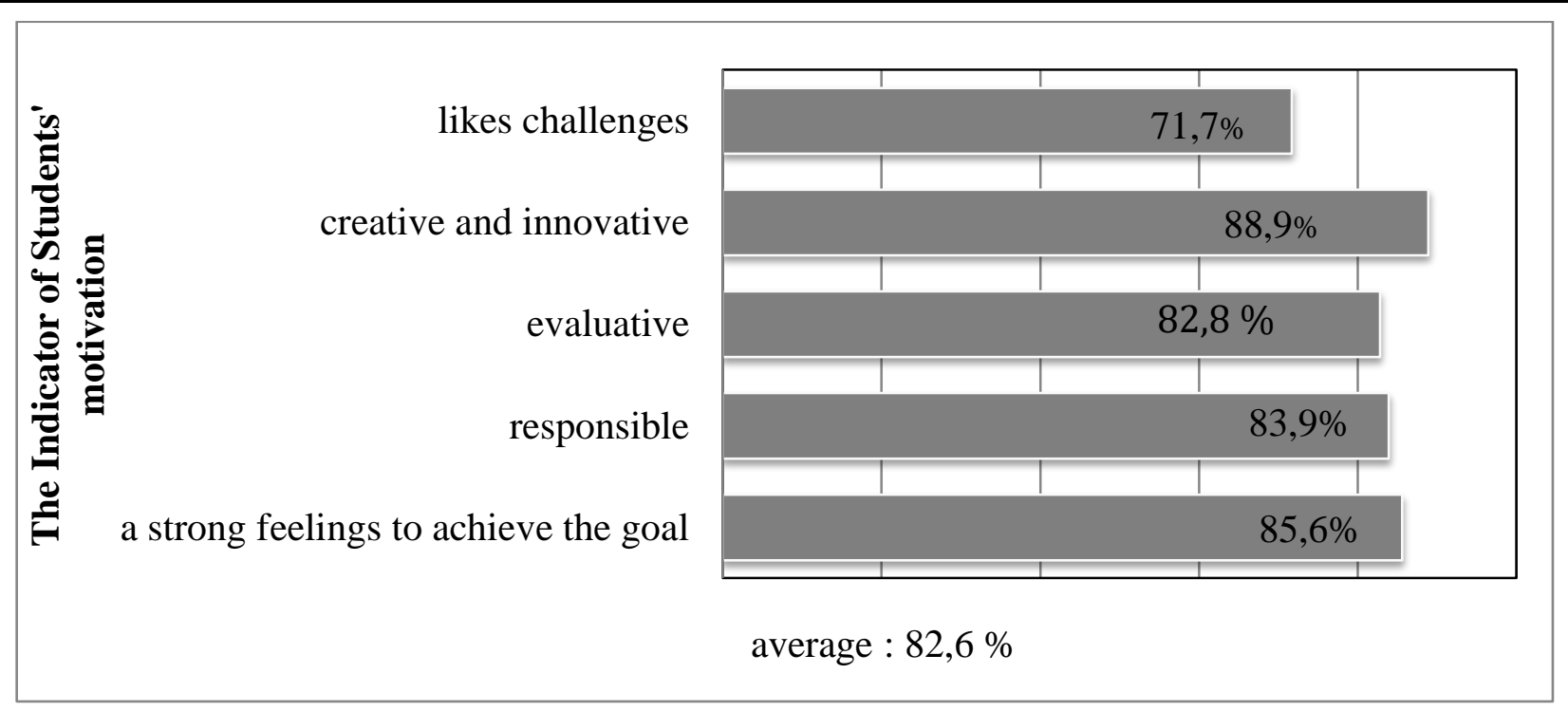

Figure 1: Percentage of Achievement Motivation on Outstanding Student in Learning Writing at Primary School

Based on the result of achievement motivation questionnaire, the percentage of achievement motivation indicator in outstanding students in learning to write explanatory text is shown in figure 1. The average answer to the questionnaire statement of outstanding students in writing learning was $82,6 \%$. This means that achievement motivation on outstanding students in learning writing is good.

1) strong feelings to achieve goals; after the data is collected it can be obtained the result of strong feeling indicator to reach the goal is $85,6 \%$. In this case students have the desire to complete the task well and have the desire to get the best results, the students feel optimistic and have hope to get good grades in learning to write explanatory text.

2) responsible; the result of responsible indicator is $83,9 \%$. The students have a good responsibility in following learning activities to write explanatory text, discipline students, earnestly and appreciate the time in doing the task. Individuals prefer tasks that demand responsibility.

3 ) evaluative; after the data is collected it can be obtained the results of evaluative indicators is $82,8 \%$. In this case, students can use more effective action feedback to achieve achievement, students learn from the failures experienced to succeed. Students who evaluate try to overcome difficulties in learning, efforts to overcome such difficulties include by asking teachers or friends who are smarter in mastering certain learning. It is clear that students immediately correct the wrong writing in the task of writing explanatory text. Besides the students asked a friend who is smarter when having difficulty in determining the main idea when got the task of writing explanatory text.

4) creative and innovative; after the data is collected it can be obtained the results of creative and innovative indicators is $88.9 \%$. The students are required to find opportunities and use opportunities to be able to develop their potential, students are able to try something new. This is evident from the ability of students in asking various questions and ability in sparking many answers given by the teacher. The results of creative and innovative indicators get the highest results, it can happen because students are used to asking questions or opinion in the classroom and are accustomed to trying something new.

5) likes challenges; after the data is collected, it can be obtained the result of indicator likes challenge is $71,7 \%$. The students will not be discouraged from doing problems in learning and always trying to solve challenges or "challenge" well. It appears that they did not avoid the task of summarizing the explanatory text despite having difficulty in writing text. They also continue to practice summarizing explanatory text vigorously despite many difficulties in writing.

\section{Describe of an interviews on outstanding students}

After the dissemination of the achievement motivation questionnaire to the next achieving students, interviews were conducted to the outstanding students in Sragen regency. Based on the findings of researchers on achievement motivation in achieving students in learning to write explanatory text, it is known that students' achievement in learning to write explanatory text in general has some achievements he has ever achieved. This means that students who excel in writing in general already have a good ability in academic competence. They have admitted that they had gained achievement in the class and had attended the competition at the primary school level. They have participated in intellgent competition meticulously, science competition and art competition.

There are several things that support student achievement motivation in learning to write explanatory text, for example, the way the teacher in delivering learning materials to write explanatory text. They have admitted that they like teachers who explain how to summarize the correct text and give them a writing exercise first, they do not like 
when the teacher just explains the material is too long and the immediately assigns the task to summarize certain texts without giving them writing execises.

Other findings in this study are achieving students in general diligent in learning, they can spend time to learn in a day. The reason they are diligent in learning is that they want to get better grades from their friends and they feel more confident in school if diligently learn.

From the results of the interviews are known to the students' achievement opinions in learning to write about the difficulties encountered in learning to write explanatory text. They have admitted that they sometimes feel lazy when getting a task to write or summarize. They have assumed that it is difficult to find the right words and difficulty putting words into sentences.

In addition, students' achievement in learning to write explanatory text gets support to become students who excel from parents and teachers. One form of support is the assistance of students in home study and assignment of summarizing the book. They have admitted that they got a writing exercise in literacy activities at school. In the literacy activities the teacher gives the task to students to read a book within a week, then after that the teacher gave the task to summarize the book they have finished reading in a week.

\section{Discussion and Conclusion}

Based on the result of the achievement motivation questionnaire. In the "strong feeling to achieve goals". It can be seen that students who have strong feelings in achieving goals are not hesitant or optimistic to get good grades because they have been practicing earnestly in writing explanatory text. Achievement students have good responsibilities in performing their duties, so they get good results too. This means success not because of luck help, but because of hard work itself. Students who have high achievement motivation always have responsibility in carrying out their duties (Febriana, 2017). If teachers can enable students to be more accountable, for example, in doing schoolwork students must collect tasks on time, discipline in learning and in following activities at school.

On the other side the results of creative and innovative indicators get the highest results, knowledge of teachers to improve the ability to think creatively and innovatively students, may be able to influence the creativity of students. The ability to think creatively is very important to support the writing of students. Research conducted by (McVey, 2008, Sturgell 2008) says that creative thinking ability is consistently associated with the skills needed for reading and writing. Another study conducted by Wang, (2012) who examines the relationship of creative thinking to read and write. The result of his research is that students who spend more time reading and writing appear significantly on tests of creative thinking. In this case that the ability to think creatively correlates to the competence of reading and writing. The ability to think creatively is very important in the development of students in learning writing. Therefore, attention and understanding of teachers on the development of students' creative thinking skills so that the writing competence of primary school students can be improved.

Based on the results of the above interviews that the fifth graders of primary school admit that writing is not easy or difficult, they find it difficult to pour ideas and ideas and choose words. As in research conducted by Kurt \& Atay, 2007, Latif, 2007, that most language learners at all levels believe that writing is one of the most difficult language skills most linguists learn at all levels to believe that writing is one of the language skills the most difficult to master. Research done by Ganopole, 1988; Collins \& Cross, 1993; Collins \& Parkhurst, 1996, that many students do not write clearly or express their ideas well when writing. But when writing, it is difficult for outstanding students to keep learning and practicing, so that in the end they can write well. This means they have an interest and motivation to write. Prakash (2007) explained that when motivation is high, students can learn a lot with little time, but when their low motivation takes longer to learn writing skills, they make a lot of mistakes in learning the material.

The achievement motivation in achieving students in learning writing is good, this happens because of several factors that support so that students excel in writing learning has a good achievement motivation, there are factors of individuals (intern) and environmental factors (external). Individual factors (internal) consists of 1) the competence of students. According to Mulyasa (2010: 16) that competence is a combination of knowledge, skills, and attitudes reflected in habitual thinking and acting, and can cause or predict changes in behavior, and measurable performance. The role of competence in achievement motivation, does not affect directly but more underlies the function and process of achievement motivation. 2) hope will succeed; hope is a visible possibility to meet the particular needs of a person or individual based on past experience. Such expectations tend to influence a person's motives, students who have the confidence to succeed in writing lessons will be more inclined to study harder to get the highest score. The environmental factors (extern) consists of 1) the existence of a competition situation (friends), in this case the students have the achievement to compete with themselves or with others, in a competition students who have motivation achievers will always try to pursue the best among friends -her friend. Achievement of outstanding students encourages students to try to get better achievement from their friends. Motivation encourages individuals to achieve success and aims to succeed in competition with a certain measure of excellence. The size of the profits may be previous achievements or achievements of others (Mc Clellend in Velmurugan, 2013).; 2) family or support from 
parents, 3) schools, including how to teach teachers. In the process of learning writing, teachers should use various teaching methods and utilize the available facilities so that learning is maximal and does not make students bored. As Saavedra and Opfer (2012) argue that learning is merely a "standard transmission" model can weaken skill development because of the lack of relevance that motivates, and ultimately lowers the level of learning. Motivation has an important role in the learning process to get better academic results (Chrishtiana, 2009, Cloud, et al, 2011, Sigh, 2011).

Thus achievement motivation has a great role to the writing in primary school. Some of the findings that support the results of this study include by Gupta, D and Woldemariam, G.S, (2011) which states motivation as one of the main strengths to improve students' writing skills. Researchers conducted by Fazel, I and Ahmadi, A. (2011) revealed that there is a relationship between motivation and writing ability. While Hashemian \& Heidari, (2013) revealed that those who have integrative motivation, have better success on writing skills. Motivation in this case is also strongly associated with achievement motivation, students who have achievement motivation will tend to be more interested to participate in learning writing because it has a passion for achievement in writing.

Based on the above description, the authors can conclude that the achievement motivation on outstanding students in learning writing is good, this happens because of several factors that support so that students excel in writing learning has a good achievement motivation, there are factors of individuals (intern) and environmental factors (external). An individual factor (intern) consists of 1) the competence of students; 2) hope or key to success or success, while environmental factors (ektern) consists of 1) the existence of competition situation (friend); 2) family or support from parents; 3) schools, including how to teach teachers. Therefore, achievement motivation of students need to get serious attention from teachers in improving writing in primary school.

\section{Acknowledgements}

An acknowledgement and thanks the authors gave to Mrs. Dr. Rukayah, M.Hum, as a Supervisor I and Mrs. Dr. Mintasih Indriayu M.Pd, as a Supervisor II which has helped this journal writing.

\section{References}

Agung, A. A. G. (2014). Metodologi Penelitian Pendidikan. Yogyakarta: Aditya Media Publising.

Awan, Ghazala, \& Anjum (2011). A study of relationship between achievement motivation, self concept and achievement in English \& Mathematic at secondary level. International Education Studies, 4(3), 72-79.

Back, R. C. (1990). Motivation: Theories and Principles. New Yersey: Prentice Hall International.

Collins, N. D., \& Cross, T. L. (1993). Teaching the writing process to gifted and talented students. Gifted Child Today, 16(3), 22-23.

Collins, N. D., \& Parkhurst, L. (1996). Teaching strategies for gifted children in the regular classroom. Roeper Review, 18, 277-279.

Christiana, 0. (2009). Influence of motivation on students' academic performance. The Sosial Sciences, 4(1), 30-36.

E. Mulyasa. (2010). Kurikulum Tingkat Satuan Pendidikan. Bandung: PT Remaja Rosda Karya.

Fazel, I., \& Ahmadi, A (2011). On the Relationship between Writing Proficiency and Instrumental/Integrative Motivation among Iranian IELTS Candidates. Theory and Practice in Language Studies, 1(7), 747-757.

Febriana, B. W. (2017). Analysis of student's achievement motivation in learning chemistry. International Journal of Science and Applied Science: Conference Series, 1(2), 17-123.

Ghasemi, F., Rastegar, A., Ghorban, J. R., \& Roozegar, M. R. (2011). The relationship between creativity and achievement motivation with high school students' entrepreneurship. Procedia - Social and Behavioral Sciences, 30, 1291-1296.

Gagne, N. L., \& Barliner, D. C. (1975). Educational Psychology. Boston: Hoghton Miflin.

Ganopole, S. J. (1988). Reading and writing for the gifted: A whole language perspective. Roeper Review, 11, 88-91.

Gupta, D., \& Woldemariam, G. S. (2011). The influence of motivation and attitude on writing strategy use of undergraduate ELF students: Quantitative and qualitative perspectives. The Asian EFL Journal Quarterly, 13(2), 7684.

Hashemian, M., \& Heidari, A. (2013). The relationship between L success in L2 writing. Procedia-Social and Behavioral Sciences, 70, 476-489.

Hassanzadeh, R., \& Mahdinejad, G. (2015). Relationship between happiness and achievement motivation : A case of university students. Journal of Elementary Education, 23(1), 53-65.

Heckhausen, H. (1967). The Anatomy of Achievement Motivation. New York: Academic Press. 
Kurt, G., \& Atay, D. (2007). The effects of peer feedback on the writing anxiety of prospective Turkish teachers of EFL. Journal of Theory and Practice in Education, 3(1), 12-23.

Lam, S. F., \& Law, Y. K. (2007). The Roles of Instructional Practices and Motivation in Writing Performance. The Journal of Experimental Education, 75(2), 145-164.

Latif, M. A. (2007). The factors accounting for the Egyptian EFL university students' negative writing affect. Essex Graduate Student Papers in Language \& Linguistics, 9, 57-82.

Moloeng, L. J. (2006). Metodologi Penelitian Kualitatif. Bandung: Remaja Rosdakarya.

Mc. Clelland, D.C., \& Terjemahan. (1987). Memacu Masyarakat Berprestasi. Jakarta: Intermedia.

McVey, D. (2008). Why all writing is creative writing. Innovations in Education \& Teaching International, 45(3), 289294.

Nurgiyantoro, B. (2014). Penilaian Pembelajaran Bahasa Berbasis Kompetensi. Yogyakarta: BPFE

Prakash, P. (2007). Psychological Foundation of Education. New Delhi: Kanishka Publishers.

Ridwan dan S. (2007). Pengantar Statistik. Bandung: CV Alfabeta.

Saavedra, A., \& Opfer, V. (2012). Teaching and Learning 21st Century Skills: Lesson from the Learning Science. A. Global Cities Education Network Report. New York: Asia Society

Sturgell, I. (2008). Touchstone texts: Fertile ground for creativity. Reading Teacher, 61(5), 411-414

Singh, K. (2011). Study of achievement motivation in relation to academic achievement of students. International Journal of Education Planning \& Administration, 1(2), 161-171.

Sugiyono. (2011). Metode Penelitian Kuantitatif, Kualitatif dan R\&B. Bandung: Alfabeta.

Sugiyono. (2012). Metode Penelitian Pendidikan Pendekatan Kualitatif, Kualitatif dan R\&D. Bandung: Alfabet.

Slavin, R. E. (1991). Educational Psychology. Theory into Practice. Englewood Cliffs: Prentice Hall International.

Uno, H. B. (2013). Teory Motivasi dan Pengukuranna (Analisis di Bidang Pendidikan). Jakarta: Bumi Aksara

Velmurugan K., \& Balakrishnan, V. (2013). Achievement motivation of higher secondary student in reation to locality and type of family. International Journal of Teacher Educational Research (IJTER), 2(23), 19-4642

Wahidmuri. (2008). Cara Mudah Menulis Proposal dan Laporan Penelitian Lapangan. Malang: UM Press.

Wang, A. Y. (2012). Exploring the relationship of creative thinking to reading and writing. Thinking Skills and Creativity, $7(1), 38-47$. 